\title{
WHEAT (TRITICUM AESTIVUM L.) PRODUCTION UNDER DROUGHT AND HEAT STRESS - ADVERSE EFFECTS, MECHANISMS AND MITIGATION: A REVIEW
}

El SABAGH, A. ${ }^{1 *}$ - Hossain, A. ${ }^{2}$ - BARUTÇULAR, C. ${ }^{3}$ - ISLAM, M. S. ${ }^{4}-$ AwAN, S. I. $^{5}$ - GALAL,

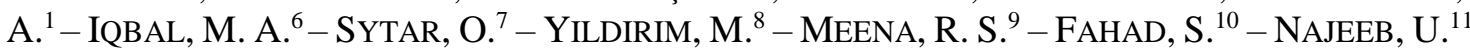
- KONUSKAN, O. ${ }^{12}$ - HABIB, R. A. ${ }^{13}$ - LlANES, A. ${ }^{14}$ - HUSSAIN, S. ${ }^{15}-$ FAROOQ, M. ${ }^{16}-$ HASANUZZAMAN, M. ${ }^{17}$ - ABDELAAL, K. H. ${ }^{18}$ - HAFEZ, Y. ${ }^{18}$ - CIG, F. ${ }^{19}$ - SANEOKA, H. ${ }^{20}$

${ }^{I}$ Department of Agronomy, Faculty of Agriculture, University of Kafrelsheikh, Egypt

${ }^{2}$ Wheat Research Center, Bangladesh Agricultural Research Institute Dinajpur-5200, Bangladesh

${ }^{3}$ Department of Field Crops, Faculty of Agriculture, University of Çukurova, Turkey

${ }^{4}$ Department of Agronomy, Hajee Mohammad Danesh Science and Technology University, Bangladesh

${ }^{5}$ Department of Plant Breeding and Molecular Genetics, Fac. of Agric., University of Poonch, Rawalakot, Pakistan

${ }^{6}$ Department of Agronomy, University of the Poonch Rawalakot (AJK), Pakistan

${ }^{7}$ Department of Plant Physiology, Faculty of Agrobiology and Food Resources, Slovak University of Agriculture,Tr. A. Hlinku 2, 94976 Nitra, Slovakia

${ }^{8}$ Department of Field Crops, Faculty of Agriculture, Dicle University, Diyarbakir, Turkey

${ }^{9}$ Deapartment of Agronomy, Inistitute of Agricultural Sciences, BHU Varanasi (UP)-221 005, India

${ }^{10}$ Agriculture Department, The University of Swabi, Khyber Paktunkhwa, Pakistan

${ }^{11}$ Queensland Alliance for Agriculture and Food Innovation, Centre for Crop Science, the University of Queensland,, Toowoomba, QLD 4350, Australia

${ }^{12}$ Department of Field Crops, Faculty of Agriculture, Mustafa Kemal University, Hatay, Turkey

${ }^{13}$ Institute of Pure and Applied Biology, Bahauddin Zakariya University, Multan, Pakistan

${ }^{14}$ Plant Physiology Laboratory, Department of Natural Sciences, FCEFQyN, Universidad Nacional de Rio Cuarto, Río Cuarto X5800, Argentina

${ }^{15}$ Department of Agronomy, University of Agriculture, Faisalabad ,38040, Punjab-Pakistan

${ }^{16}$ Department of Crop Sciences, College of Agricultural and Marine Sciences, Sultan Qaboos University, Al-Khoudh-123, Oman

${ }^{17}$ Department of Agronomy, Faculty of Agriculture, Sher-e-Bangla Agricultural University, Dhaka1207,Bangladesh

${ }^{18}$ EPCRS Excellence Center, Plant Pathology and Biotechnology Lab., Agriculture Botany

Department, Faculty Agriculture, Kafrelsheikh University, 33516, Egypt

${ }^{19}$ Department of Field Crops, Faculty of Agriculture, Siirt University, Turkey

${ }^{20}$ Pant nutritional physiology, Graduate School of Biosphere Science, Hiroshima University, Japan

*Corresponding author

e-mail:ayman.elsabagh@agr.kfs.edu.eg

(Received $18^{\text {th }}$ Feb 2019; accepted $1^{\text {st }}$ May 2019) 


\begin{abstract}
Heat and drought stresses are the most important abiotic factors that reduce crops productivity by affecting various physiological and biochemical processes. Thus, selecting cultivars with better drought or heat stress tolerance or breeding for stress tolerance will be helpful in enhancing crop productivity under harsh environments. This review elaborates the physiological basis of high temperature and drought stress tolerance in wheat which can be used as selection criteria in wheat breeding program. In addition, some agronomic selection criteria which are valid and useful in selecting stress tolerant wheat species and cultivars. The review also discussed the valid usage of stress tolerance indices (such as mean productivity (MP), geometric mean productivity (GMP), yield index (YI), yield stability index (YSI), relative productivity (RP\%), stress susceptibility index (SSI), and the tolerance index (TOL)) to scan the genotypes against drought and heat stress. Beside these, exogenous application of stress signaling compounds, osmolytes, or certain inorganic salts play a vital role for alleviating adverse effects of abiotic stresses for sustainable wheat production. In addition, applications for soil amendments will also helpful in increasing wheat crop productivity under stressful conditions. All these strategies may be helpful to meet the food demands of the increasing population.
\end{abstract}

Keywords: wheat, drought, heat stress, stress tolerance indices, agronomic approaches

Abbreviations: AsA, ascorbic acid; CAT, catalase; DRI, drought resistance index; ES, early sowing; GB, glycine betaine; GMP, geometric mean productivity; GY, grain yield; HSI, heat susceptibility index; MP, mean productivity; LS, late sowing; OS, optimum sowing; POX, peroxidase; RH, relative humidity; $\%$ RP, relative performance; SSI, stress susceptibility index; Se, selenium; SA, salicylic acid; STIs, stress tolerance indices; TOL, tolerance index; YE, Yeast extract; YI, yield index; YSI, yield stability index

\title{
Introduction
}

Wheat (Triticum aestivum L.) is one of the leading cereals and used as a staple food for 1.2 billion people worldwide (Afzal et al., 2015; Iqbal et al., 2018). To feed the increasing population, the global demand for wheat is expected to increase up to $40 \%$ by 2050 to meet the food security (Rosegrant and Agcaoili, 2010; Abdelaal et al., 2018; Jahan et al., 2019). In view of the global climate change, drought ,salinity and heat stresses are the major abiotic constraints for wheat productivity and adversely affects the yield and quality through altering the physiological activity (Kosina et al., 2007; Otu et al., 2018; Yassin et al., 2019). Short or long-term exposure to heat and drought stresses can significantly affect the growth and yield, particularly at sensitive growth stages (Prasad et al., 2008). Hoegh - Guldberg et al. (2018) estimated that due to climate change and $2-3^{\circ} \mathrm{C}$ rise in global temperature, losses of wheat yield will increase by up to $30 \%$ by 2050 . As water availability is a major factor limiting crop production in many parts of the world, the management practices focus on enhancing water use efficiency of the future crops (Majid et al., 2017). In addition, drought tolerance traits must be incorporated in crops anticipating the climate changing scenario (EL-Shawy et al., 2017). To cope climate change, selection of suitable varieties as well as optimization of irrigation water are needed for maintaining sustainable food supplies (Bernardi, 2011).

Various approaches are suggested to overcome crop losses due to drought and heat stresses such as stress management practices, breeding for developing stress-tolerant cultivars, use of physiological mechanisms in developing stress tolerant cultivars and exogenous use of chemicals which improve stress tolerance (Farooq et al., 2011; Hossain and Teixeira da Silva, 2012, 2013). Since most of the modern wheat varieties are not sufficiently tolerant to drought and heat (Alghabari et al., 2015), development of wheat cultivars that are tolerant to drought and heat is one of the main challenges for wheat breeders around the world (EL Sabagh et al., 2018a). The present review aimed to assess the current status of knowledge of the physiological basis of stress tolerance in plants, the applicability of this knowledge in developing stress tolerant crop cultivars, 
limitations or deficiencies in understanding mechanism of stress tolerance, and efficiency of different approaches in mitigating adverse effects of drought and heat stress on plants. In other words, the main objective of the present review is to rationalize the physiological breeding for drought and heat stress tolerance in wheat. This will help in deciding future directions in developing high yielding wheat cultivars under heat and drought stress conditions.

\section{Impacts of drought and heat stress on phenology, growth, and productivity of wheat}

A temperature above or below the optimum can hamper the growth and development of wheat crop by influencing various processes such as uptake of water and nutrients, however, such effects may vary with plant developmental stages (Wahid et al., 2007). Under high temperature, the crop completes its life cycle relatively faster which ultimately lead to decrease the final biomass and yield (Rahman et al., 2009; Nahar et al., 2010; Hakim et al., 2012; Hossain et al., 2009, 2011, 2012a, b, c, 2013, 2017,2018). In the Sub-Tropical region of South-Asia such as Pakistan, India, Bangladesh, delayed planting significantly reduces the days to maturity and grain filling period and grain yield of wheat (Mahboob et al., 2005). Similarly, Barutcular et al. (2016b, c; Y1ldirım et al.,2018) noticed that delayed planting cause the exposure of wheat plants to high temperature and moisture stress that resulted in a reduction in growth and yield of wheat. In view of these reports, it is suggested that efforts should focus on identifying drought and heat resistant ideotypes and selection should be based on yield traits to increase the economic yield under heat and drought stress conditions. However, traits responsible for drought and/or heat resistance in wheat are not well defined. Drought tolerance in crop species can be defined as the ability of crop cultivar to produce satisfactory harvestable yield under water deficit conditions (Basu et al., 2016). However, yield stability is better to stress tolerance indicator under heat stress or water stress conditions (Fleury et al., 2010). In addition, a little progress has been made in identifying key mechanisms associated with high yield and stress tolerance against high temperature and drought stress (Ogbaga et al., 2018).

\section{Drought and heat stress in relation to sowing time}

\section{Days to germination}

Seed germination in wheat is one of the most critical growth stages that influence initial plant population, stand establishment, and finally yield of wheat under stress condition (Almansouri et al., 2001). Environmental factors such as seed-bed soil moisture, temperature, as well as seed vigour/quality, play an important role in seed germination and stand establishment of the crops (Khajeh-Hosseini et al., 2003). Since soil moisture availability and temperature both regulate seed germination, lower moisture and/or low soil temperature hinder or delay seed germination which results in unequal seedling establishment and ultimately reduce the final grain yield of crops (Hampson and Simpson, 1990; Hossain et al., 2012). Generally, in the arid and semiarid region, seed germination in spring wheat occurs at the range of air and soil temperature of $20-30^{\circ} \mathrm{C}$ (Hossain et al., 2012a,b,c). However, late sown (LS) wheat crop takes longer time to germinate than sown at optimum sowing in temperate region (like Russia), due to reduced soil moisture and low temperature $\left(<12^{\circ} \mathrm{C}\right)$ (Hossain and Teixeira da Silva, 2012; Hossain et al., 2012b; Fig. 1). 
The impact of heat stress in combination with deficit soil moisture (drought stress) is the most critical to impact seed germination than the individual stress (Al-Karaki et al., 2007; Hossain et al., 2013). Similarly, Hossain and Teixeira da Silva (2012) found significant differences in days to germination among the three wheat varieties in OS (optimum sowing) and LS (late sowing) conditions (Fig. 2). They found that the days to germination were increased by 25 to $50 \%$ in late sown condition due to a low temperature at germination, while under OS, all varieties showed no variation in germination time (Fig. 3; Hossain and Teixeira da Silva, 2012). Likewise, while conducting a field experiment Chakrabarti et al. (2011) reported that air temperature greater than $15^{\circ} \mathrm{C}$ is appropriate for seed germination and seedling stand establishment of spring wheat.

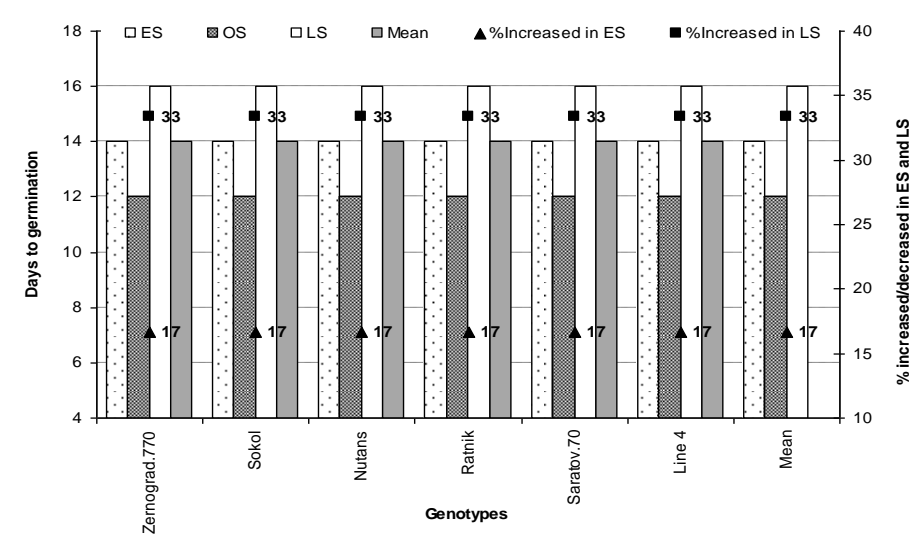

Figure 1. Days to start germination of wheat and barley as influenced by low temperature in early sown and high temperature with drought stress in late sown condition in the arid region of south-eastern Russia; ES, early sowing; OS, optimum sowing; LS, late sowing (Source:

Hossain et al., 2012b)

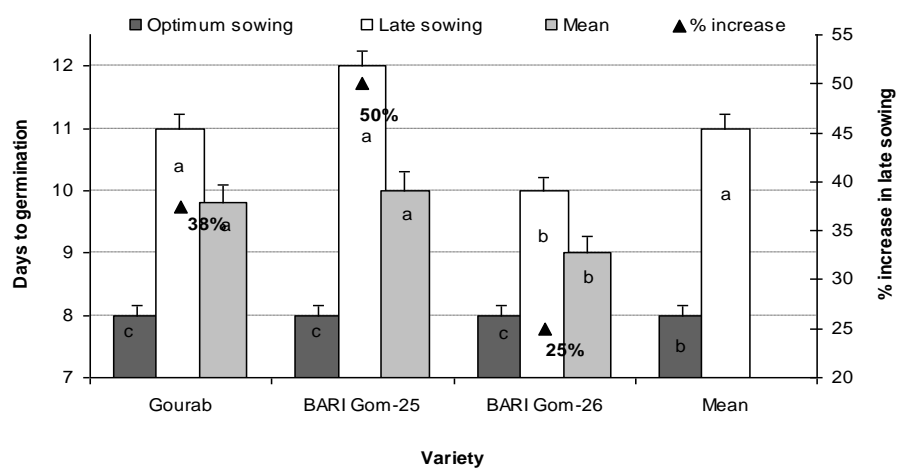

Figure 2. Days to seed germination of three wheat varieties as influenced by late sown heat stress conditions in the north-western part of Bangladesh (Source: Hossain and Teixeira da Silva, 2012)

\section{Days to booting}

The reproductive stages are the most sensitive to high temperature and drought stress (Foolad, 2005). Heat stress induced by late sowing of wheat reduced days to booting by 4$14 \%$ in variety 'Shatabdi', 'BARI Gom 27 and 'BARI Gom 28' in the north-western part of Bangladesh (Hossain and Teixeira da Silva, 2012; Hossain et al., 2017; Fig. 4). Similarly, 
Hakim et al. (2012) noticed that days to maturity in different wheat cultivars were significantly decreased under late sown condition (LS) as compared to optimum sowing (OS), which was probably due to heat stress at the reproductive phase. These reports suggested that number of days to attain specific phenological stage are affected by the change in sowing date and alterations in soil moisture availability and prevailing temperature. However, such effects were lesser for drought and heat stress tolerant wheat cultivars (Hassanuzzaman et al., 2013).

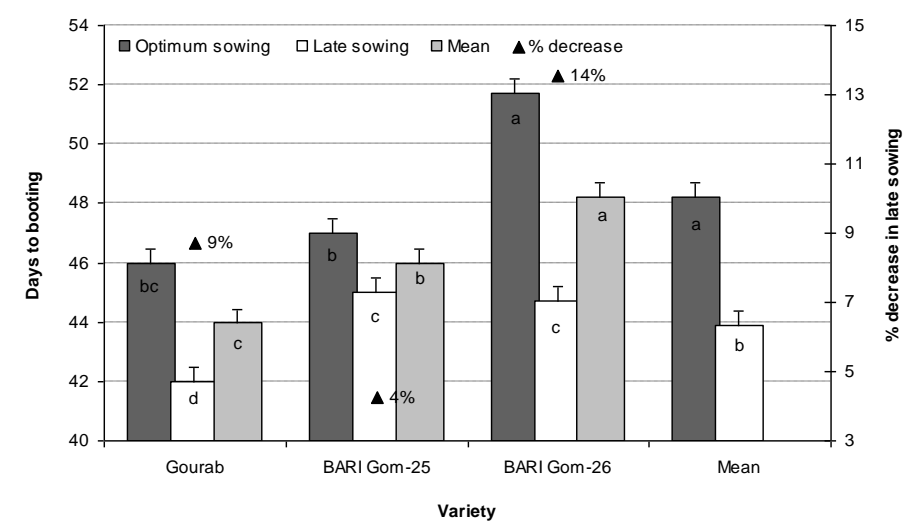

Figure 3. Days to booting of wheat varieties as influenced by very late sown heat stress conditions in north-western part of Bangladesh. (Source: Hossain and Teixeira da Silva, 2012)

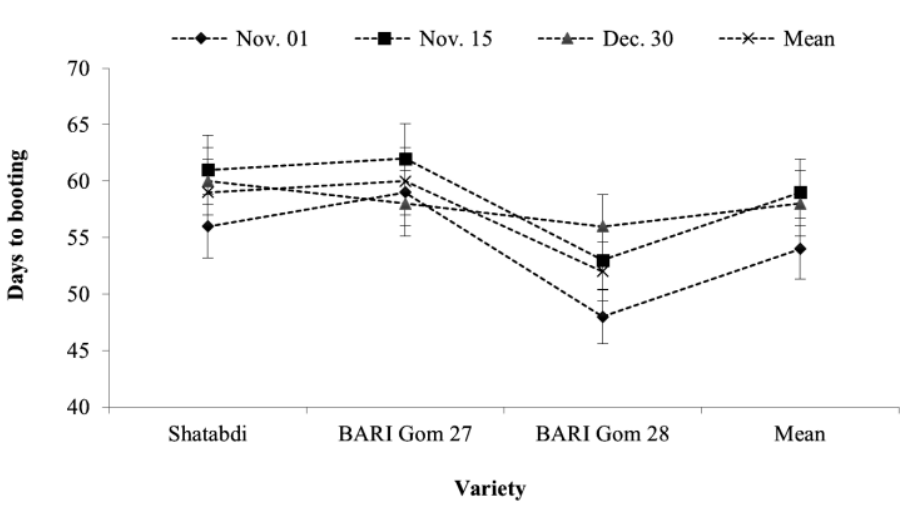

Figure 4. Number of days to booting in three wheat varieties when sown on three different dates in North-Western Bangladesh (Source: Hossain et al., 2017)

\section{Days to first awn development}

Ear emergence or first visble awn developmental stage is sensitive to heat stress. For example, Foolad (2005) reported that heat stress is most detrimental to wheat crops at the first awn development stage and this heat sensitivity in wheat continues up to 10 to 15 days after flowering. Hossain and Teixeira da Silva (2012) found a considerable genetic variation in days to first visible awn in late sowing wheat genotypes (Fig. 5). They further added that such variation in first awn development was associated with degree of sensitivity to heat stress.

Similarly, Reynolds et al. (2000) reported a reduction in the crop growth period in response to the shortage of favourable resources under heat stress, resulting in low total plant biomass, finally low grain yield. Nahar et al. (2010) also found a decrease in the life span of 
wheat under late sown induced heat stress condition in Bangladesh. In their study, in late sown condition, the maximum temperature at vegetative and reproduction phases were 25 to $27^{\circ} \mathrm{C}$ and 30 to $32^{\circ} \mathrm{C}$, respectively. However, under environmental condition of south-eastern part of Russian, Hossain et al. (2012b) observed that wheat and barley genotypes took a long time until the first visible awn in early sowing as compared to optimum and late sowing, due to the delay of germination and a long period of vegetative growth due to the low of temperature (Fig. 6). They also reported that days to first awn visible was reduced by 19 to 25\% (Fig. 6) in late sowing conditions, due to high temperature in combined with drought stress (Hossain et al., 2012b). From these reports, it is clear that soil moisture availability and high temperature shorten the time to visible awn, which might have been due to the adverse impact on plant metabolism and available resources.

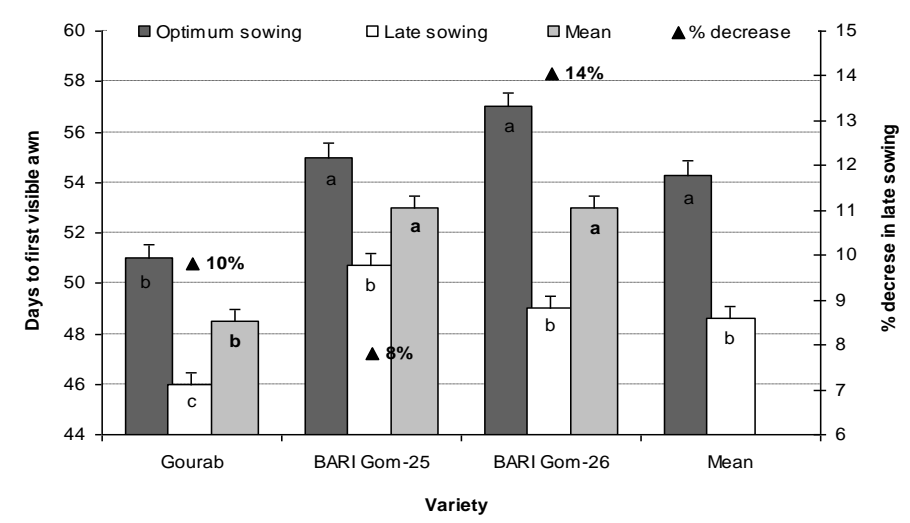

Figure 5. Number of days to the first visible awn of wheat varieties sown at different dates. Due to different sowing times, wheat plants become exposed to different temperatures at a specific growth stage (Source: Hossain and Teixeira da Silva, 2012)

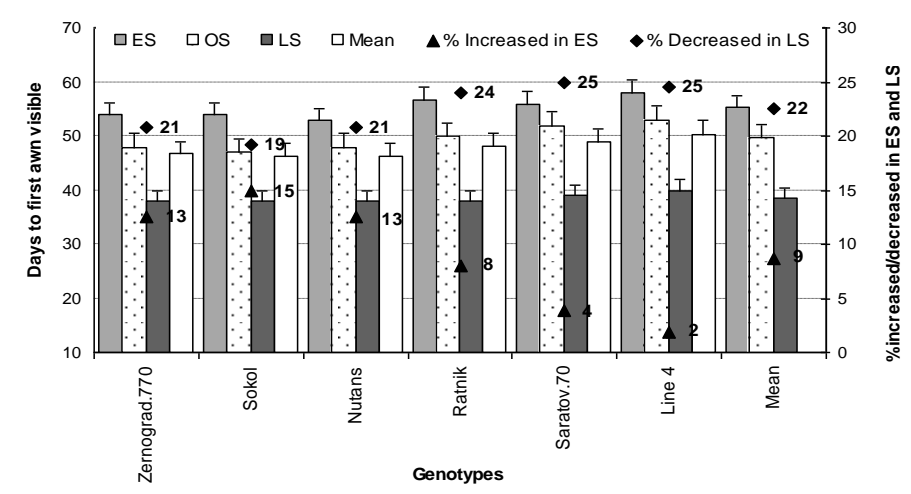

Figure 6. Days to first awn visible of wheat and barley is influenced by low-temperature at early sown and high temperature with drought stress at late sown condition in the south-eastern part of Russia (Source: Hossain et al., 2012b)

\section{Days to anthesis}

Development of flowers with visible mature anthers is called anthesis stage in wheat. Flowering is regulated by temperature, duration of light and dark (photoperiodic) and plant vigour. Change in temperature alters the time of flowering in wheat plants by changing sowing time. It has been observed that anthesis time can be modulated by 
15-20 days (Reynolds and Trethowan, 2007; Prasad et al., 2008). By optimizing sowing date, the temperature at the anthesis stage can be modulated in wheat plants which may favour fertilization. In the environmental condition of Bangladesh, Hossain and Teixeira da Silva (2012) carried out a field research in north-western part of Bangladesh with three wheat varieties sown at optimum (OS) and late sowing (LS) conditions and observed that all evaluated wheat varieties took less time to anthesis, due to the harmful effect of high temperature and drought and all varieties decreased the life span from 10 to $21 \%$ to complete anthesis (Fig. 7).

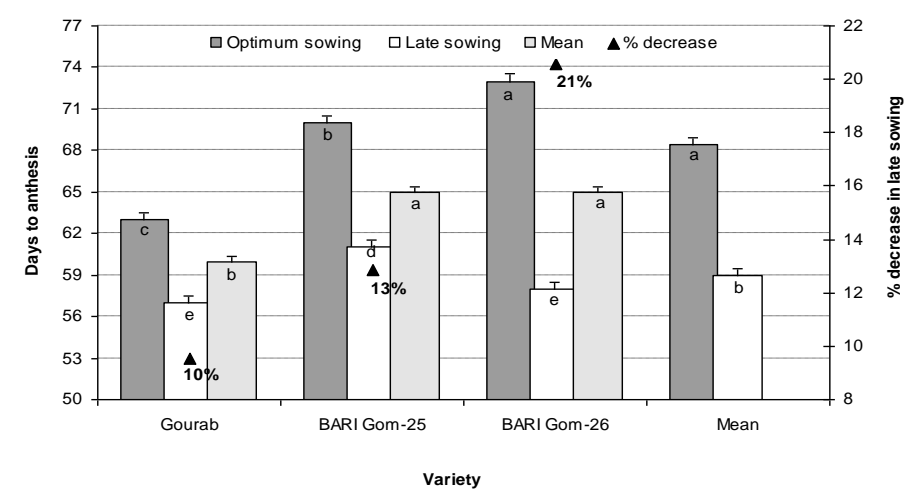

Figure 7. Days required to anthesis of wheat varieties are influenced by the very late sown heat stress condition in the climatic condition of north-western Bangladesh (Source: Hossain and Teixeira da Silva, 2012)

Similar results were also reported by Ubaidullah et al. (2006), who found that late sown wheat faced adverse effect of high temperature $\left(25-33^{\circ} \mathrm{C}\right)$ stress at a reproductive stage under the condition of Pakistan that ultimately leads to decrease the yield of wheat. However, heat stress tolerant wheat cultivars had a lesser impact on yield. These reports suggested that exposure of wheat plants to episodes of high temperature at the initial stage of reproductive phase cause yield losses due to either shortening of plant growth period or due to adverse effects of high temperature on fertilization, or grain filling process. It is already well established that high temperature affects meiosis and gametogenesis in anthers which results in poor development of pollen grain and hence fertilization.

\section{Days of physiological maturity}

Under stress condition, most of the crops try to finish their developmental phases within a shorter period of time (Hakim et al., 2012; Hossain et al., 2012a,b,c, 2013). Araus et al. (2007) argued that environmental factors such as temperature and drought accelerate the time to reach different growth stages of wheat but this effect may vary with the type of cultivar and stress imposition at the specific phenological stage. Ubaidullah et al. (2006) found that heading, grain-filling and physiological maturity period of wheat crops in Pakistan were significantly different with the change in sowing time. Similarly, Prasad et al. (2008) found that late-sown spring wheat took fewer days to anthesis, grain-filling, and physiological maturity due to exposure to heat stress in India. The effect of heat stress on late-sown heat wheat crops was also confirmed by Hossain and Teixeira da Silva (2012) (Fig. 8) in the north-western climate condition of 
Bangladesh, where they observed that a temperature $>30^{\circ} \mathrm{C}$ during grain-filling forced late-sown crop to mature earlier than the crop sown at the optimum time. These reports suggested that detailed understanding of differential sensitivity to varying temperature and soil moisture availability induced by different sowing times in different agroecological zones is necessary for selection of superior wheat genotypes.

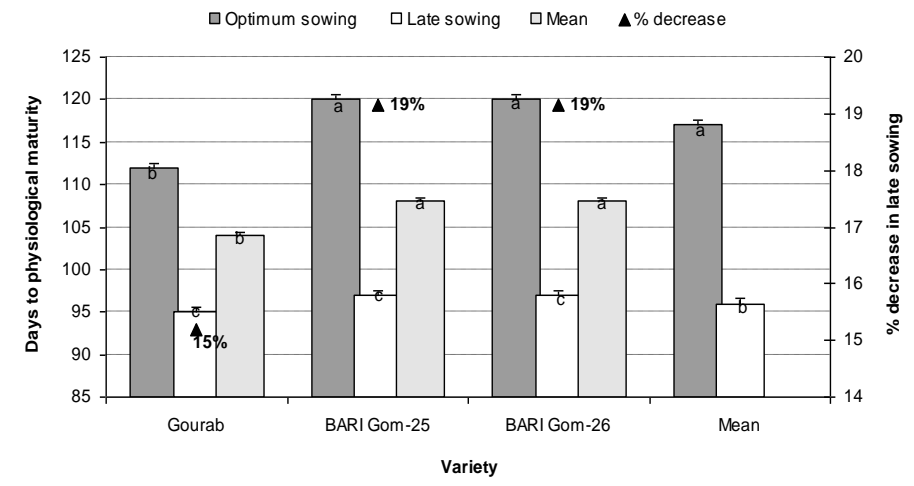

Figure 8. Required days to physical maturity of three wheat varieties are influenced by very late sown heat stress conditions of north-western Bangladesh (Source: Hossain and Teixeira da Silva, 2012)

\section{Growth and development of wheat as affected by drought and heat stress}

High temperatures along with low moisture availability particularly in late sown crop reduced the growth and yield of spring wheat in different agro-ecological regions of the world including the arid and semi-arid region of the Mediterranean environment. Heat stress in late sown induced accelerate leaf senescence, abscission of the shoot and cause poor root growth (Vollenweider and Gunthardt-Goerg, 2005; Martiniello and Teixeira da Silva, 2011). These reports suggested that the adverse effect of heat stress due to late sowing reduced the wheat growth and yield by affecting vegetative growth traits that are translated in to yield. Understanding the effects of heat and soil moisture availability on these agronomic traits and its relationship with wheat yield will help in devising management strategies to overcome this problem.

\section{Plant population of wheat in relation to stress tolerance}

Plant population of field crops generally depends on seed rate, genotypes, germination percentage and seed-bed environment, especially soil moisture and temperature (Khajeh-Hosseini et al., 2003; Hossain et al., 2013). Similarly, Wazid et al. (2004), Hossain et al. (2012a,b,c) and Mumtaz et al. (2015) observed that the number of plants $\mathrm{m}^{-2}$ was higher in early sown wheat genotypes followed by optimum sowing and late sowing. Planting density was strongly influenced by the availability of soil moisture and favourable temperature at germination. They also reported that plants $\mathrm{m}^{-2}$ reduced by $12-70 \%$ in late sowing due to low temperature and low soil moisture. Al-Karaki et al. (2007) reported that the combined effect of high air temperature and drought was critical for reducing the per cent seed germination, finally plant population was lower under combined stresses than the individual stress. Hampson and Simpson (1990) and Hossain et al. (2012b; Fig. 9) reported that soil moisture deficit postpones the germination rate of wheat, causes unequal plants per unit area, and finally reduce the 
seed yield and quality of wheat. Although above-mentioned reports suggested that temperature variation during seed germination affect plant density which results in lower yield, there are published reports which demonstrated that plant density 80-400 plants $/ \mathrm{m}^{2}$ did not show any change in yield because of other factors such as tillering (Fischer et al., 2019).

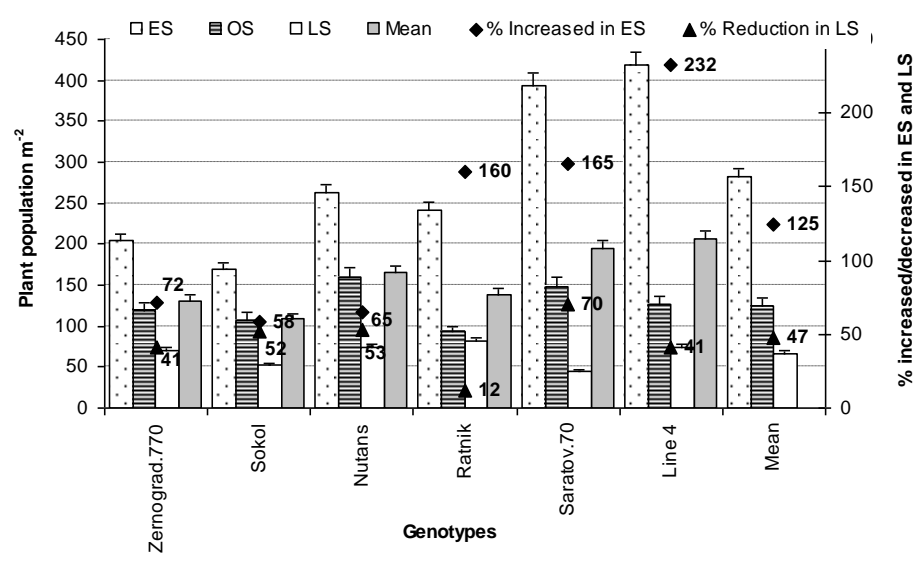

Figure 9. Plants $m^{-2}$ of all wheat \& barley genotypes is affected by low (early sowing) and high temperature with drought (late sowing) in the environmental condition of south-eastern part of Russia (Source: Hossain et al., 2012b)

However, the yield of spring wheat cultivars with erect growth habit planted at higher altitude is highly sensitive to plant density and row spacing. In addition, yield sensitivity to plant density and row spacing is moderate in winter wheat. However, at low soil moisture availability, optimum plant density become reduced (Fischer et al., 2019).

\section{Tillering capability of wheat under heat and drought stresses}

Wheat tillers generally grow from the axils of the main shoot leaves, the potential numbers of tillers depend on the type of species or its genetic makeup and prevailing temperature (Hossain et al., 2012a,b). Shifting in sowing dates (early or late sown) change temperature at a specific plant reduced the number of tillers (Patil et al., 2001; Singh and Pal, 2003; Subhani, 2010). While assessing the impact of different planting dates on tillering in wheat in a two-year experiment in Pakistan, Mumtaz et al. (2015) reported that late sowing reduced the number of tillers. They further added that the reduction in the number of tillers per unit area is positively associated with an increased temperature at the tillering stage. Upadhyay et al. (2015) stated that numbers of effective tillers were significantly superior for crop sown on $20^{\text {th }}$ November followed by $10^{\text {th }}$ December, to late sown on $30^{\text {th }}$ October. The effective number of tillers decreased with early and delayed sowings, due to environmental stresses (Herbek and Lee, 2009; Hossain et al., 2012b; Fig. 10). Although a substantial amount of evidence is available that number of tillers per unit area is co-determined by cultivar characteristics, agronomic practice such as sowing date and environmental factors mainly thermal conditions, developing general consensus on phenological responses to changing sowing dates as climate warming is not an easy task because of different genetic makeup of different wheat cultivars. 


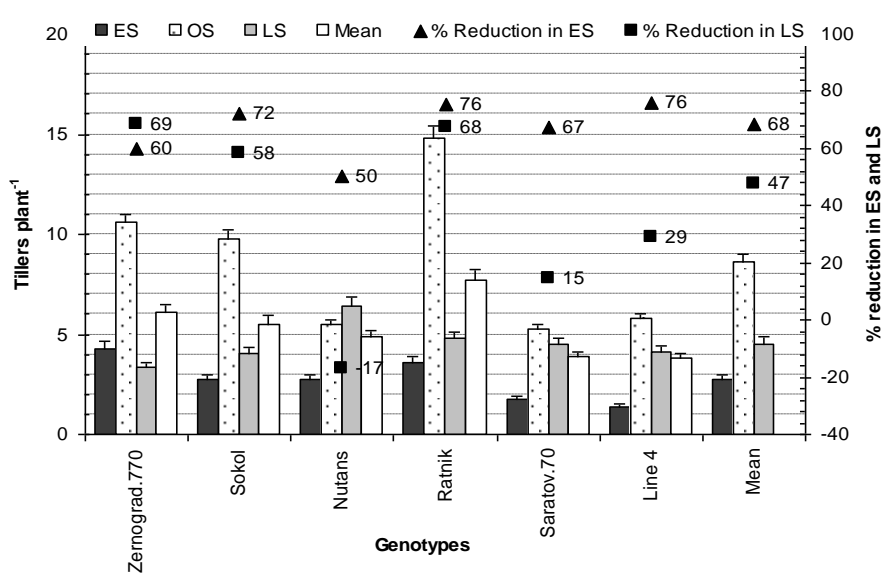

Figure 10. Tillers plant ${ }^{-1}$ of all wheat and barley genotypes is influenced by low-temperature stress in early sowing and high temperature combine with drought in late sowing conditions (Source: Hossain et al., 2012b)

Dry matter partitioning of wheat and barley genotypes as influenced by hightemperature

Under favourable environment, 80 to $90 \%$ of the carbohydrates is translocated to the grain and rest of 10 to $20 \%$ is reserve to wheat plant's (Spiertz and Vos, 1985). Ahamed et al. (2010) found that dry matter partitioning and yield in five wheat varieties was influenced by the heat stress $\left(30\right.$ to $\left.32^{\circ} \mathrm{C}\right)$ under late sowing. Hossain et al. (2012b; Fig. 11) found that most of the existing spring wheat and barley genotypes in the southeastern part of Russia were highly sensitive to high temperature and drought in late sown condition, whereas in early sowing generally rainfed spring wheat and barley face low-temperature stress. Despite a higher plant population in early sowing, tillers production plant $^{-1}$ was low due to low-temperature stress. This caused 10 to $42 \%$ reduction in dry biomass of early-sown crop. While, the late sown crop suffered 57 to $81 \%$ reduction in dry biomass due to high temperature (with low soil moisture and low relative humidity in air) that ultimately affected rate of seed germination (Fig. 9), tillers plant $^{-1}$ (Fig. 10), and grain yield (Reynolds et al., 2000; Hossain et al., 2012b; Fig. 11).

Gupta et al. (2002) found the maximum dry weight in wheat genotypes under optimum sown conditions as compared to those of late sown conditions. The late sown wheat genotypes faced unfavourable conditions during germination to reproductive stages that ultimately lead to decreased final biomass accumulation of wheat cultivars. Similarly, Jat et al. (2013) found the maximum dry matter at optimum sown crops as compared to late sown crops. Ahamed et al. (2010) conducted an experiment with five wheat varieties ('Sourav', 'Pradip', 'Sufi', 'Shatabdi' and 'Bijoy') under two sowing times (at November 30 and December 30) and found the highest dry matter partitioning in 'Shatabdi' under heat stress environment but 'Prodip' and 'Sufi' produced the lowest dry matter partitioning, which indicated that dry matter partitioning of a genotype fully depend on genetic makeup of the specific variety. Similarly, Khichar and Niwas (2007) reported that delayed sowing resulted in a decrease in biomass and grain yields, due to the unfavourable environment during late sown conditions, especially high temperature and water deficit. Mondal et al. (2016) also reported that optimizing of sowing date can significantly enhance biomass yield of wheat. These reports suggested that 
environmental factors affect plant metabolism associated with translocation of photoassimilates from source to sink.

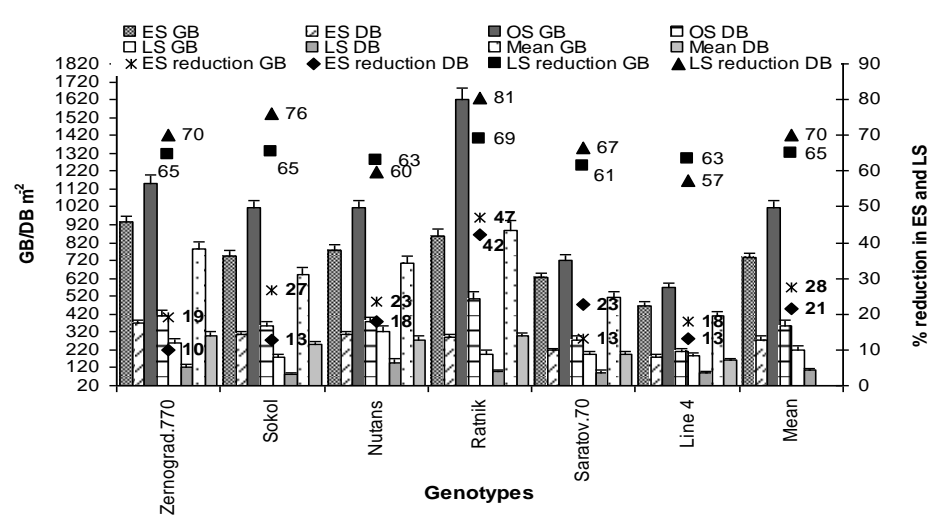

Figure 11. Dry and green biomass of rainfed spring wheat and barley are affected by in early sowing low-temperature stress and heat stress in combination with drought stress in late sowing conditions in south-eastern part of Russia. GB-green biomass and DB-dry biomass (Hossain et al., 2012b)

\section{Plant height of wheat and barley genotypes as affected by high-temperature stress}

Hossain et al. (2012b) observed a significant genotypic and environmental effect on the height of wheat genotypes under early and late sown conditions (Fig. 12). They also found that plant height in early and late sowing was lower, due to low-temperature in early sowing, while high temperature combined with drought in late sowing (Hossain et al., 2012b; Fig. 12). It is suggested that prevailing temperature at early growth stage regulated plant height probably through gibberellic acid biosynthesis or GA signaling response pathway.

\section{Yield and yield attributes of wheat genotypes influenced by heat and drought stress}

Tillers $\mathrm{m}^{-2}$, spikes $\mathrm{m}^{-2}$, grains spike ${ }^{-1}$, number of fertile tillers $\mathrm{m}^{-2}, 1000$-grain weight, spike length, spike weight, stem weight and awn length in wheat are considered most important yield contributing characters that are positively correlated with final grain weight of wheat and thus are the most important parameter for screening wheat genotypes in breeding programs (Forgone, 2009). However, drought and heat are the two significant environmental factors that limiting crop productivity through influencing the yield attributes of wheat (Prasad et al., 2008). However, interaction of environmental and genetic factors has a significant role in obtaining high productivity as reported by Shahin and Valiollah (2009). Maralian et al. (2010) observed that tillering and heading stages were sensitive to drought, and can reduce up to $37 \%$ grain yield. Mirbahar et al. (2009) reported that drought stress significantly decreased the spike length, spikelets per spike, grains spike $^{-1}$ and 1000-grain weight of wheat. The maximum reduction in all traits was observed in terminal drought, while post- and preflowering drought significantly influenced the 1000-grain weight (Abdoli et al., 2013).

Grain yield of wheat genotypes is strongly influenced by heat stress. Hossain and Teixeira da Silva (2012) found that the grain yield of wheat varieties significantly decreased when sown late compared with optimum sowing time (Fig. 13). Similarly, Barutçular et al. (2017) reported that cultivation of wheat under heat stress conditions 
recorded significantly lower grain yield. The inhibited kernel weight at maturity was the result of high temperature which shortened the grain filling period (Wardlaw, 2002). The grain yield reduction in wheat was associated with delayed sowing, which exposed the reproductive phase of plants to high temperature (Mostafa et al., 2009). Menshawy (2007) found that delayed sowing reduced the grain yield by shortening the grain filling process, and kernels achieved maturity before completion of filling.

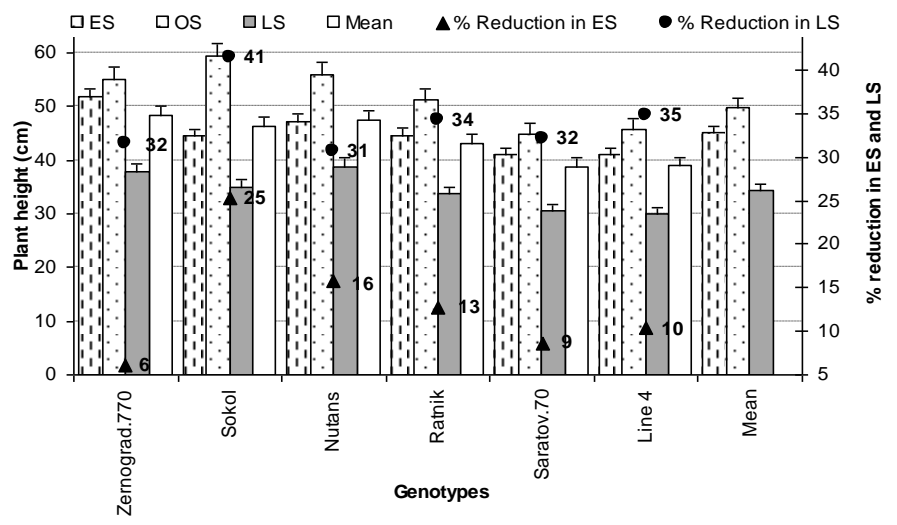

Figure 12. Plant height $(\mathrm{cm})$ of wheat and barley genotypes is influenced by low-temperature stress in early sowing and high temperature combine with drought stress in late sowing conditions (Hossain et al., 2012b)

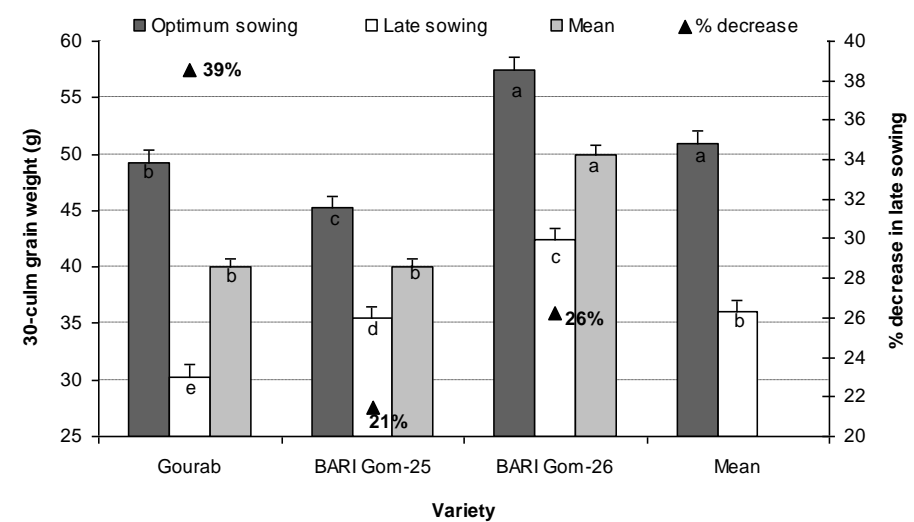

Figure 13. Grain yield of wheat varieties is influenced by late sown heat stress condition (Hossain and Teixeira da Silva, 2012)

Stone and Nicolas (1994) reported that high temperature during grain filling reduced grain weight and pre-anthesis decreased the grain number in wheat (Wardlaw et al., 1989; Wardlaw and Moncur, 1995). Subedi et al. (2007) found variation in grain yield and yield attributes among wheat genotypes grown at delay sowing comparing optimum sowing could be attributed through hampering of grain filling process that is high temperatures arisen at late sown wheat shortened the grain filling period.

The occurrence of drought stress along with the high temperature in the arid region is the most frequent after heading and grain filling that remarkably influences grain yield of wheat crop (Balla et al., 2011; Saleh, 2011). Hozayn and El-Monem (2010) reported that the decrease in growth and yield attributes of wheat might be due to water stress 
during grain filling stage; while Zeidan et al. (2009) associated grain yield reduction in wheat with drought-induced photosynthetic inhibition.

\section{Physiological and biochemical traits}

High-temperature and water availability influence the photosynthetic capacity of plants including wheat (Chaves et al., 2009; Efeoglu et al., 2009). Chlorophyll content and stem reserves are very sensitive to high-temperature (Mohammadi et al., 2009). Singh (2009) observed the variation in the thermo-tolerance and physiological traits of wheat varieties under high-temperature stress. Hence, leaf chlorophyll content could be used as an indicator to determine the performance of the photosynthetic rate and reflect the photosynthetic potential (Hussain et al., 2018). Li et al. (2006) found that drought tolerance in wheat genotypes was associated with leaf chlorophyll content. Xia (2012) reported that heat, as well as drought stress tolerance, was positively associated with photosynthetic capacity. Recently, Ogbaga et al. (2018) suggested that developing thermos-tolerance in photosynthetic machineries such as in rubisco or rubisco activase will result in enhanced crop productivity. Stay-green plants have been used to select for yield stability and a selection criterion for heat stress tolerance in wheat (Joshi et al., 2007; Christopher et al., 2008). Reynolds and Trethowan (2007) reported that leaf chlorophyll content or stay-green was correlated with the leaf transpiration efficiency, which enhances the water use efficiency (WUE) under drought stress conditions. The studies on the stay-green trait of wheat genotypes are largely elusive (Rehman et al., 2009) and are yet to be evaluated for their association with stress tolerance in the wheat (Cao et al., 2015). Yeganehpoor et al. (2016) noticed that grain yield had a significant positive correlation with leaf area and chlorophyll content. Furthermore, chlorophyll content can simultaneously enhance grain yield, and plants with large leaves and higher chlorophyll content can also produce higher grain yield. These reports suggested that the amount of chlorophyll regulates the light harvesting capacity of plants which is sensitive to both heat and drought stress. In addition, photosynthetic pigment sensitivity to abiotic stresses is cultivar specific in wheat, thus could be used as selection criteria for selecting tolerant cultivars.

The reduction in the $\mathrm{CO}_{2}$ assimilation rate in drought-stressed plants is mainly due to the reduction in leaf stomatal conductance (Chaves et al., 2009). Therefore, stomatal conductance could be used as a reliable indicator of growth rate responses to drought stress at the whole plant or canopy level (Munns et al., 2010). However, metabolism limitation to photosynthesis in drought or heat stressed plants are also well established. For example, the reduction in photosynthesis is the result of adverse effects on the metabolic process that lead to growth inhibition, stomatal closure with consecutive reduction of transpiration (Yordanov et al., 2003). Similarly, Zhang et al. (2009) reported that the soluble carbohydrate content was lower in stressed plants than that well-watered wheat plants. Araus et al. (2007) reported that leaf physiological aspects such as water potential, chlorophyll content, photosynthetic rate, stomatal conductance, and transpiration rate are associated with the physiological adaptation of crops to environmental stress. Increase in transpiration lowers the plant water status which affects cell division and cell enlargement. For example, Manivannan et al. (2007) suggested that water deficit can significantly reduce leaf area development in wheat genotypes by arresting the cell enlargement. Similarly, Almeselmani et al. (2011) reported that relative water content (RWC) indicates the water status of the cells and have a positive correlation with production and stress tolerance. However, transpiration 
through stomates regulates leaf or canopy temperature. For instance, when transpiration rate is low in wheat plants under drought stress conditions, the canopy temperatures of plants at both vegetative and anthesis stages were higher than in plants under control conditions (Siddique et al., 2000). Balota et al. (2007) proposed that low canopy temperature can be used as a selection criterion for drought tolerance in wheat.

Reactive oxygen species (ROS) are generated in chloroplast, mitochondria and in the cytoplasm upon explore to heat and drought stresses and can cause membrane damage (Larkindale and Knight, 2002). The reduction in the activity of ROS scavenging enzymes has been found under drought conditions (Ahmadi and Baker, 2001). Maria et al. (2008) reported that water deficit could significantly reduce phenoloxidase activity of wheat plants, however, such effect is lesser in stress tolerant genotypes. Although an increase in activities of one or more than two ROS scavenging enzymes may have a role in inducing stress tolerance, it is not necessary that higher activities of ROS scavenging enzymes are associated with stress tolerance. Membrane damage due to ROS generation can be assessed by measuring the extent of lipid peroxidation or leaf electrolyte leakage. Under stress, cellular membrane permeability of plants become increased and often correlated with reduced growth of wheat (Iqbal, 2009). The heat tolerant cultivars had lower leaf electrolyte leakage under heat stress (Thiaw and Hall, 2004) and selection based on low leaf electrolyte leakage can be used as selection criteria for enhancing heat and drought tolerance. Proline accumulation enhances membrane stability under heat or drought stress conditions (Ashraf and Foolad, 2007). The accumulation of proline with high rate in leaves under stressed occurs during the grain filling phase under moderate stress and the role of proline is correlated to a protective action against stress (Zhu et al., 2004). Sugar alcohols enhance the stability of membranes and protein to hightemperature denaturation (Heber and Santarius, 1973).

\section{Correlation among yield attributes and stress tolerance}

In the previous section, some physiological indicators for heat and drought stress have discussed. However, agronomic traits and their derived parameters can also be used as selection criteria in the breeding program. Here we describe the importance of agronomic criteria in brief. The relationship between the stress tolerance indices (STIs) and grain yield $(\mathrm{GY})$ can be used to screen the wheat genotypes that are suitable to grow under stress conditions. A positive relationship between GY and each of (stress tolerance indices) MP, GMP, YI, YSI, and RP\% were observed (Khan and Kabir, 2014). Mitra (2001) suggested that a significant correlation between GY and STIs of a genotype is suitable to grow under heat stress conditions. Such correlations also hold true for other stresses such as drought. Toorchi et al. (2012) and Khalili et al. (2012) reported that GY was positively correlated with each of GMP, MP, YI, and YSI under heat stress conditions.

The mean values of drought resistance index (DRI) are used for characterizing drought and heat stress tolerance and adaptation of genotypes to stress conditions. Drought stress index (DSI) was negatively correlated with grain yield under cool supplement irrigation. Moreover, heat stress index (HSI) was also positively correlated with grain yield under warm conditions inferring that heat stress was more effective for grain yield than drought stress under the warm environment. The higher values of DRI indicated more tolerance in wheat genotypes under stress environments and might be used as stress tolerant index (STI) in wheat breeding programs (EL-Shawy et al., 2017; Barutçular et al., 2016a, 2017). Since modern wheat varieties are not sufficiently 
stressed tolerant, developing cultivars tolerant to heat is challenging for wheat breeders (Timsina and Connor, 2001). Rahman et al. (2009) found that stress resistance genotype had a higher value (\%) of relative performance (RP \%). Similarity, compared with RP\% at late sown condition (high temperature and drought) genotype 'Nutans' (57\%) performed better than 'Saratov.70' (18\%), while at early sowing low-temperature stress condition, genotype 'Zernograd.770' (74\%) was highly resistant to low-temperature stress and 'Saratov.70' (27\%) was recorded as heat sensitive (Hossain and Teixeira da Silva, 2012; Fig. 14).

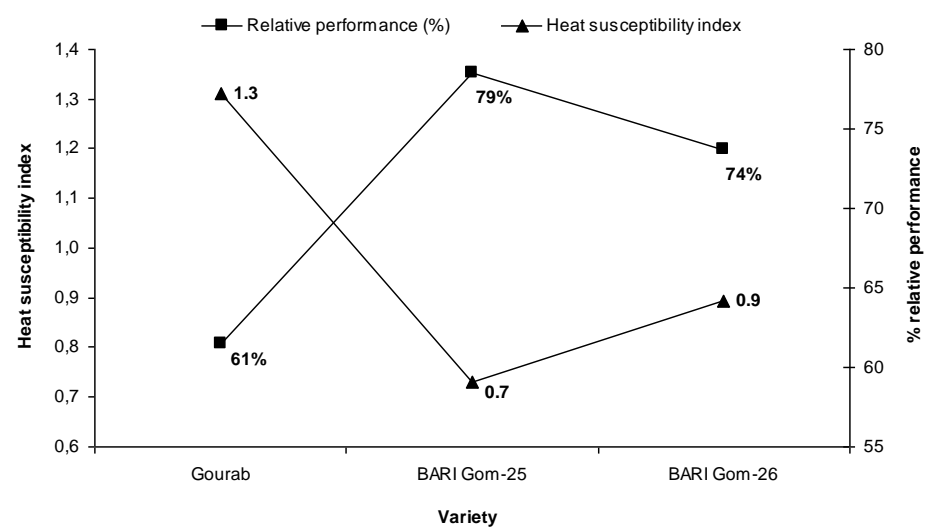

Figure 14. Relative performance (\%) and heat susceptibility index of three wheat varieties in very late heat stress condition, as compared with optimum sowing (Hossain and Teixeira da Silva, 2012)

Similarly, Hossain et al. (2012a) found that three genotypes had SSI higher than 1.0 under late sowing condition (high temperature) indicating susceptible to stress, while other two genotypes (SSI <1, indicating tolerant to high temperature in combined with drought) (Fig. 15). A number of researchers suggested that stress tolerance indices (STIs), stress tolerance (TOL) (Rosielle and Hamblin, 1981), mean productivity (MP) (Clarke and McCaig, 1982), geometric mean productivity (GMP) (Ramirez and Kelly, 1998), stress susceptibility index (SSI) (Fischer and Maurer, 1978), and STI (Fernandez, 1992) can be used to identify high-yielding varieties with improved tolerance to stress.

\section{Approaches to enhance drought and heat stress tolerance in wheat}

Development and selection of wheat genotypes are aimed at enhancing yield under existing climatic conditions. Various strategies including seed dressing/coating, seed soaking, and foliar application of plant growth regulators, osmoprotectants and antioxidants have been used to enhance stress tolerance in wheat plants. Moreover, another organic compound like yeast extract (YE) is a natural source of several growth substances that positively effect to mitigate the deleterious influence of drought stress (Hammad and Ali, 2014). Barnett et al. (1990) found that YE has a significant role in regulating vegetative and reproductive growth of plant under stress condition. Nagodawithana (1991) found that exogenous application of amino acids or yeast on wheat lead to a significant improvement in all growth traits under stress conditions compared to control. El-Nabarawy (2001) reported that amino acids or yeast play a significant role in the synthesis of chlorophyll content. Furthermore, Wanas (2002) 
recorded that the yeast improved the chlorophyll while delayed the degradation and senescence in plants. Osmoregulators protect plants through osmotic adjustment by maintaining membrane integrity, protecting the macromolecular structure, and stabilization of proteins and enzymes (Ashraf and Foolad, 2007; Hayat et al., 2012). There are several reports indicating that abiotic stress triggers the accumulation of proline in plant tissues (Slama et al., 2014). Moreover, exogenous application of proline caused an increase in endogenous level in plants subjected to water stress conditions and induced plant tolerance (Ashraf and Foolad, 2007; Ali et al., 2008). Glycine betaine (GB) plays an essential role in the protection of photosynthetic apparatus from photodamage (Zhao et al., 2007), and involvement of GB in the regulation of the activities of antioxidant enzymes has been reported by Wang et al. (2010).
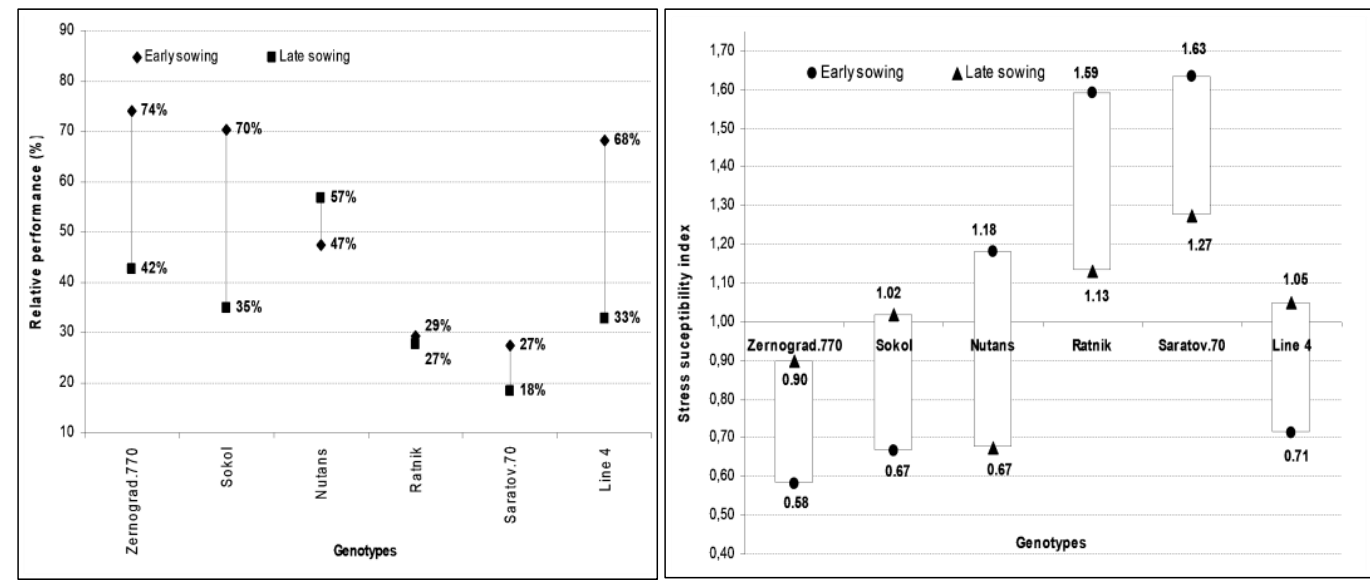

Figure 15. Relative yield performance (\%) and stress susceptibility index of different genotypes under ES-early sowing and LS-late sowing (Source: Hossain et al., 2012a)

In addition to osmoprotectants, antioxidants are also being used to regulate stress tolerance such as salicylic acid, ascorbic acid etc. Salicylic acid (SA) is useful for the establishment of systemic acquired resistance in plants (Larkindale and Huang, 2005). Ascorbic acid (AsA), is an antioxidant that plays a beneficial role in cell growth and division, differentiation and metabolism in plants (Athar et al., 2009). Xu et al. (2015) observed that foliar application of AsA ameliorates the adverse effects of drought stress by controlling the stomatal closure, nutrient uptake, total chlorophyll content, protein synthesis, transpiration, photosynthesis, and plant growth. Bakry et al. (2012) applied AsA aiming to control pattern of growth and development coupled with improvement of systemic tolerance against different stressful environments of plants and they reported that AsA enhances plants growth to survive under stress conditions by changing plant structure and function.

Recently, selenium (Se) has been reported to counteract with the detrimental effects of various environmental stresses such as excess water stress (Wang et al., 2010), chilling (Hussain et al., 2016a,b), submergence (Hussain et al., 2016c) and hightemperature stress (Djanaguiraman et al., 2010). It may regulate water status (Kuznetsov et al., 2003), and increase biomass production (Nawaz et al., 2013) by the activation of antioxidant apparatus of water-stressed plants (Hasanuzzaman and Fujita, 2011). 


\section{Conclusion and future prospect}

The drought and heat stresses may occur simultaneously under natural environments and cause huge crop losses. Thus, selecting cultivars with better drought or heat stress tolerance or breeding for stress tolerance will help in developing stress tolerant cultivars to enhance crop productivity under harsh environmental conditions. The present review synthesizes and elaborates the physiological basis of high temperature and drought stress tolerance in wheat which can be used as selection criteria in wheat breeding program. In addition, some agronomic selection criteria which are valid and useful in selecting stress tolerant wheat cultivars. In addition, to mitigate the adverse effects of these stresses on wheat, optimization of production technology package especially sowing dates, selection of appropriate irrigation at critical growth stages, and/or development of drought and heat-tolerant cultivars will help to sustain grain yield production. Application of natural bio-stimulants, especially amino acids lead to overcome the damaging effects and consequently lead to enhance the growth and yield of wheat under stress environments. In addition, exogenous application of signaling compounds, osmolytes, and certain inorganic salts play a significant role in alleviating stress. Any suitable combinations of these management strategies can enhance stress tolerance of wheat in the Mediterranean environment and similar eco-regions elsewhere. Beside these approaches, applications for soil amendments will also helpful in increasing wheat crop productivity under stressful environments. The review also discussed a positive and negative correlation between (grain yield) GY and stress tolerance indices (such as mean productivity (MP), geometric mean productivity (GMP), yield index (YI), yield stability index (YSI), relative productivity (RP\%), stress susceptibility index (SSI), and the tolerance index (TOL)) to scan the genotypes against drought and heat stress. In the future, stress adversities might be minimized by improving tolerance in genotypes and by adopting better agronomic strategies. In the present review, field phenotyping for heat and drought stress tolerance in wheat discussed at length which is based on visual scoring, weighing biomass, stress tolerance indices and physiological traits. However, such practices are time consuming and labor intensive. With the advent of artificial intelligence, robotics, communication and immage processing large number of studies are focused on high throughput phenotyping using spectral sensors and algorithms to assess in depth genotypic variation at specific growth stages. Such advance phenoimic approaches not only helped in identifying physiological responses of crops to drought and heat stress, it will aid in developing stress tolerant crop cultivars. Global interest will increase in this area of research in future for agricultural sustainability.

Conflict of interests. Authors declared no conflict of interests.

\section{REFERENCES}

[1] Abdoli, M., Saeidi, M., Jalali-Honarmand, S., Mansourifar, S., Eghbal-Ghobadi, M. E. (2013): Evaluation of some physiological and biochemical traits and their relationships with yield and its components in some improved wheat cultivars under post-anthesis water deficit. - Environmental Stresses in Crop Sciences. 6(1): 47-63. [In Persian with English Summary]. 
[2] Abdelaal, Kh. A. A., Omara, I. R., Hafez, M. Y., Samar, M. E., EL Sabagh, A. (2018): Anatomical, Biochemical and Physiological Changes in Some Egyptian Wheat Cultivars Inoculated with Puccinia gramini f. sp. tritici f. sp. tritici f.sp. tritici. - Fresenius Environmental Bulletin 27(1): 296-305.

[3] Afzal, M. I., Muhammad, A. I., Zahid, A. C. (2015): Triggering growth and boosting economic yield of late-sown wheat (Triticum aestivum L.) with foliar application of allelopathic water extracts. - World Journal of Agricultural Sciences 11(2): 94-100.

[4] Ahamed, K. U., Nahar, K., Fujita, M. (2010): Sowing date mediated heat stress affects the leaf growth and dry matter partitioning in some spring wheat (Triticum aestivum L.) cultivars. - The IIOAB Journal 1(3): 1-9.

[5] Ahmadi, A., Baker, D. A. (2001): The effect of water stress on grain filling processes in wheat. - Journal of Agricultural Science 136: 257-269.

[6] Alghabari, F., Ihsan, M. Z., Hussain, S., Aishia, G., Daur, I. (2015): Effect of Rht alleles on wheat grain yield and quality under high temperature and drought stress during booting and anthesis. - Environmental Science and Pollution Research 20: 15506-15515.

[7] Ali, Q., Ashraf, M., Shahbaz, M., Humera, H. (2008): Ameliorating effect of foliar applied proline on nutrient uptake in water stressed maize (Zea mays L.) plants. Pakistan Journal of Botany 40: 211-219.

[8] Al-Karaki, G. N., Al-Ajmi, A., Othman, Y. (2007): Seed germination and early root growth of three barley cultivars as affected by temperature and water stress. - AmericanEurasian Journal of Agricultural and Environmental Science 2(2): 112-117.

[9] Almansouri, M., Kinet, J. M., Lutts, S. (2001): Effect of salt and osmotic stresses on germination in durum wheat (Triticum durum Desf.). - Plant and Soil 231: 243-254.

[10] Almeselmani, M., Abdullah, F., Hareri, F., Naaesan, M., Ammar, M. A., Kanbar, O. Z., Saud, A. (2011): Effect of drought on different physiological characters and yield component in different Syrian durum wheat varieties. - Journal of Agricultural Science 3: 127-133.

[11] Araus, J., Ferrio, J., Buxo, R., Voltas, J. (2007): The historical perspective of dry land agriculture: lessons learned from 10000 years of wheat cultivation. - Journal of Experimental Botany 58(2): 131-145.

[12] Ashraf, M., Foolad, M. R. (2007): Roles of glycine betaine and proline in improving plant abiotic stress resistance. - Environmental and Experimental Botany 59: 206-216.

[13] Athar, H. R., Khan, A., Ashraf, M. (2009): Inducing salt tolerance in wheat by exogenously applied ascorbic acid through different modes. - Journal Plant Nutrition 32: 1799-1817.

[14] Bakry, A. B., Abdelraouf, R. E., Ahmed, M. A., El Karamany, M. F. (2012): Effect of drought stress and ascorbic acid foliar application on productivity and irrigation water use efficiency of wheat under newly reclaimed sandy soil. - Journal of Applied Scientific Research 8(8): 4552-4558.

[15] Balla, K., Rakszegi, M., Li, Z. G., Bekes, F., Bencze, S., Veisz, O. (2011): Quality of winter wheat in relation to heat and drought shock after anthesis. - Czech Journal of Food Science 29: 117-128.

[16] Balota, M., Payne, W. A., Evett, S. R., Lazar, M. D. (2007): Canopy Temperature Depression Sampling to Assess Grain Yield and Genotypic Differentiation in Winter Wheat. - Crop Science 47: 1518-1529.

[17] Barnett, J. A., Payne, R. W., Yarrow, D. (1990): Yeast Characteristics and Identification. - second ed. Press, Cambridge Univ., London, UK, 1012 p.

[18] Barutçular, C., EL Sabagh, A., Konuskan, O., Saneoka, H., Yoldash, K. M. (2016a): Evaluation of maize hybrids to terminal drought stress tolerance by defining drought indices. - Journal of Experimental Biology and Agricultural Sciences 4: 610-616.

[19] Barutcular, C., Yıldırım, M., Koç, M., Akıncı, C., Tanrıkulu, A., EL Sabagh, A., Saneoka, H., Ueda, A., Islam, M. S., Toptas, I., Albayrak, O., Tanrikulu, A. (2016b): 
Quality traits performance of bread wheat genotypes under drought and heat stress conditions. - Fresenius Environmental Bulletin 25(12a): 6159-6165.

[20] Barutcular, C., Yildirim, M., Koc, M., Akinci, C., Toptac, I., Albayrak, O., Tanrikulu, A., El Sabagh, A. (2016c): Evaluation of SPAD chlorophyll in spring wheat genotypes under different environments. - Fresenius Environmental Bulletin 25(4/2016a): 12581266.

[21] Barutçular, C., EL Sabagh, A., Koç, M., Ratnasekera, D. (2017): Relationships between Grain Yield and Physiological Traits of Durum Wheat Varieties under Drought and High Temperature Stress in Mediterranean Conditions. - Fresenius Environmental Bulletin 26(4): 4282-4291.

[22] Basu, S., Ramegowda, V., Kumar, A., Pereira, A. (2016): Plant adaptation to drought stress. - F1000Research, 5, F1000 Faculty Rev-1554. doi:10.12688/f1000research.7678.1.

[23] Bernardi, M. (2011): Understanding user needs for climate services in agriculture. Bulletin, Volume 60(2). <http://www.wmo.int/pages> (Accessed on 06 April 2019).

[24] Cao, X., Mondal, S., Cheng, D. (2015): Evaluation of agronomic and physiological traits associated with high temperature stress tolerance in the winter wheat cultivars. Acta Physiologiae Plantarum 37: 90. doi:10.1007/s11738-015-1835-1836.

[25] Chakrabarti, B., Singh, S. D., Nagarajan, S., Aggarwal, P. K. (2011): Impact of temperature on phenology and pollen sterility of wheat varieties. - Australian Journal of Crop Science 5(8): 1039-1043.

[26] Chaves, M. M., Maroco, J. P., Pereira, J. S. (2003): Understanding plant response to drought- from genes to the whole plant. - Functional Plant Biology 30: 239-264.

[27] Christopher, J. T., Manschadi, A. M., Hammer, G. L., Borrell, A. K. (2008): Stay green wheat for Australia's changing dry environment. - In: Appels, R., Eastwood, R., Lagudah, E., Langridge, P., Mackay, M., McIntyre, L., Sharp, P. (eds.) $11^{\text {th }}$ International wheat genetics symposium 2008-Proceedings, vol 1. Sydney University Press, Sydney, pp 119-120.

[28] Clarke, J. M., McCaig, T. N. (1982): Evaluation of techniques for screening for drought resistance in wheat. - Crop Science 22(3): 503-506.

[29] Djanaguiraman, M., Prasad, P. V. V., Seppanen, M. (2010): Selenium protects sorghum leaves from oxidative damage under high temperature stress by enhancing antioxidant defense system. - Plant Physiology and Biochemistry 48(12): 999-1007.

[30] Efeoglu, B., Terzioglu, S. (2009): Photosynthetic responses of two wheat varieties to high temperature. - European Asia Journal of Biological Science 3: 97-106.

[31] El-Nabarawy, M. A. (2001): Mitigation of dark induced senescence. 1 - By some amino acids. - Annals of Agriculture Science Moshtohor University 39(1): 225-232.

[32] EL Sabagh, A., Hossain, A., Barutçular, C., Anjorin, F., Islam, M. S., Ratnasekera, D., Kizilgeçi, F., Yadav, G. S., Yıldırım, M., Saneoka, H. (2018a): A revıew on varıous factors which affectıng sustainable maize (Zea mays 1.) production under drought stress. Journal of Experimental Biology and Agricultural Sciences 5(6): 779-794.

[33] EL-Shawy, E. E., EL Sabagh, A., Mansour, M., Barutcular, C. (2017): A comparative study for drought tolerance and yield stability in different genotypes of barley (Hordeum vulgare L.). - Journal of Experimental Biology and Agricultural Sciences 5(2): 151-162.

[34] Farooq, M., Bramley, H., Palta, J. A., Siddique, K. H. (2011): Heat stress in wheat during reproductive and grain-filling phases. - Critical Review of Plant Science 30: 491-507.

[35] Fernandez, G. C. J. (1992): Effective selection criteria for assessing stress tolerance. - In: Kuo, C. G. (ed.) Proc. Int. Sym. Adaptation of Vegetables and Other Food Crops in Temperature and Water Stress, Publication, Tainan, Taiwan.

[36] Fischer, R. A., Maurer, R. (1978): Drought resistance in spring wheat cultivars. I. Grain yield response. - Australian Journal of Agricultural Research 29: 897-907. 
[37] Fischer, R. A., Ramos, O. M., Monasterio, I. O., Sayre, K. D. (2019): Yield response to plant density, row spacing and raised beds in low latitude spring wheat with ample soil resources: An update. - Field Crops Research 232: 95-105.

[38] Fleury, D., Jefferies, S., Kuchel, H., Langridge, P. (2010): Genetic and genomic tools to improve drought tolerance in wheat. - Journal of Experimental Botany 61(12): 32113222.

[39] Foolad, M. R. (2005): Breeding for abiotic stress tolerances in tomato. - In: Ashraf, M., Harris, P. J. C. (eds.) Abiotic Stresses: Plant resistance through breeding and molecular approaches, The Haworth Press Inc., New York, USA. p. 613-684.

[40] Forgone, A. G. (2009): Physiological indicators of drought tolerance of wheat. - Biology $\mathrm{PhD}$ Program. University of Szeged Faculty of Science and Informatics Department of plant Biology, Szeged.

[41] Gupta, N. K., Shukla, D. S., Pande, P. C. (2002): Interaction of yield determining parameters in late sown wheat genotypes. - Indian Journal of Plant Physiology 7(3): 204269.

[42] Hakim, M. A., Hossain, A., Teixeira da Silva, J. A., Zvolinsky, V. P., Khan, M. M. (2012): Yield, protein and starch content of 20 wheat (Triticum aestivum L.) genotypes exposed to high temperature under late sowing conditions. - Journal of Scientific Research 4(2): 477-489.

[43] Hammad, S. A. R., Ali, O. A. M. (2014): Physiological and biochemical studies on drought tolerance of wheat plants by application of amino acids and yeast extract. Annals of Agricultural Science 59(1): 133-145.

[44] Hampson, C. R., Simpson, G. M. (1990): Effect of temperature, salt and osmotic potential on early growth of wheat (Trticum aestivum L.). I. Germination. - Canadian Journal of Botany 68: 524-528.

[45] Hasanuzzaman, M., Fujita, M. (2011): Selenium pretreatment upregulates the antioxidant defense and methylglyoxal detoxification system and confers enhanced tolerance to drought stress in rapeseed seedlings. - Biological Trace Element Research 143(3): 17581776.

[46] Hasanuzzaman, M., Nahar, K., Alam, M., Roychowdhury, R., Fujita, M. (2013): Physiological, biochemical, and molecular mechanisms of heat stress tolerance in plants. - International Journal of Molecular Sciences 14(5): 9643-9684.

[47] Hayat, S., Hayat, Q., Alyemeni, M. N., Wani, A. S., Pichtel, J., Ahmad, A. (2012): Role of proline under changing environments: A review. - Plant Signaling and Behavior 7: 111.

[48] Heber, U., Santaius, K. A. (1973): Cell death by cold and heat and resistance to extreme temperature. Mechanisms of hardening and dehardning. - In: Prechts, H., Christophersen, J., Hensel, H., Larcher, W. (eds.) Temperature and life. pp: 232-263.

[49] Herbek, J., Lee, C. (2009): A Comprehensive Guide to Wheat Management in Kentucky. - U.S. Department of Agriculture, M. Scott Smith, Director, Cooperative Extension Service, University of Kentucky College of Agriculture, Lexington, and Kentucky State University, Frankfort. <http://www.uky.edu/Ag/GrainCrops/ID125Section2.htm> (Last accessed 13 February 2018). (Last accessed 24 May 2019).

[50] Hoegh-Guldberg, O., Jacob, D., Taylor, M., Bindi, M., Brown, S., Camilloni, I., Diedhiou, A., Djalante, R. (2018): Impacts of $1.5^{\circ} \mathrm{C}$ global warming on natural and human systems. - In: Global Warming of $1.5^{\circ} \mathrm{C}$ an IPCC special report on the impacts of global warming of $1.5^{\circ} \mathrm{C}$ above pre-industrial levels and related global greenhouse gas emission pathways, in the context of strengthening the global response to the threat of climate change. Chapter 3. Intergovernmental Panel on Climate Change. International Institute for Applied Systems Analysis (IIASA) - Schlossplatz 1 - A-2361 Laxenburg, Austria. Available link: http://pure.iiasa.ac.at/id/eprint/15518/.

[51] Hossain, M. M., Hossain, A., Alam, M. A., EL Sabagh, A., Khandakar Faisal Ibn Murad, Haque, M. M., Muriruzzaman, M., Islam, M. Z., Das, S., Barutcular, C., Kizilgeci, F. 
(2018): Evaluation of fifty spring wheat genotypes grown under heat stress condition in multiple environments of Bangladesh. - Fresen. Environ. Bull. 27: 5993-6004.

[52] Hossain, A., Sarker, M. A. Z., Saifuzzaman, M., Akhter, M. M., Mandal, M. S. N. (2009): Effect of sowing dates on yield of wheat varieties and lines developed since 1998. Bangladesh Journal of Progressive Science and Technology 7(1): 5-8.

[53] Hossain, A., Sarker, M. A. Z., Hakim, M. A., Lozovskaya, M. V., Zvolinsky, V. P. (2011): Effect of temperature on yield and some agronomic characters of spring wheat (Triticum aestivum L.) genotypes. - International Journal Agricultural Research Innovation and Technology 1(1): 44-54.

[54] Hossain, A., Teixeira da Silva, J. A. (2012): Phenology, growth and yield of three wheat (Triticum aestivum L.) varieties as affected by high temperature stress. - Notulae Scientia Biologicae 4(3): 97-106.

[55] Hossain, A., Teixeira da Silva, J. A., Lozovskaya, M. V., Zvolinsky, V. P., Mukhortov, V. I. (2012a): High temperature combined with drought affect rainfed spring wheat and barley in south-eastern Russia: yield, relative performance and heat susceptibility index.Journal of Plant Breeding and Crop Science 4(11): 184-196.

[56] Hossain, A., Teixeira da Silva, J. A., Lozovskaya, M. V., Zvolinsky, V. P. (2012b): High temperature combined with drought affect rainfed spring wheat and barley in SouthEastern Russia: I. Phenology and growth. - Saudi Journal of Biological Sciences 19(4): 473-487.

[57] Hossain, A., Teixeira da Silva, J. A., Lozovskaya, M. V., Zvolinsky, V. P. (2012c): The Effect of High Temperature Stress on the Phenology, Growth and Yield of Five Wheat (Triticum aestivum L.) Genotypes. - The Asian and Australasian Journal of Plant Science and Biotechnology 6(1): 14-23.

[58] Hossain, A., Teixeira da Silva, J. A. (2013): Wheat production in Bangladesh: its future in the light of global warming. - AoB Plants published online January 8, 2013, 5: pls042 (Annals of Botany Company). doi: 10.1093/aobpla/pls042.

[59] Hossain, A., Sarker, M. A. Z., Saifuzzaman, M., Teixeira da Silva, J. A., Lozovskaya, M. V., Akhter, M. M. (2013): Evaluation of growth, yield, relative performance and heat susceptibility of eight wheat (Triticum aestivum L.) genotypes grown under heat stress. International Journal of Plant Production 7(3): 615-636.

[60] Hossain, A., Islam, M. R., Rahman, K. A. M. M., Rashid, M. H., Anwari, A. (2017): Comparative performance of three wheat (Triticum aestivum L.) varieties under heat stress. - International Journal of Natural and Social Sciences 4(3): 26-42.

[61] Hozayn, M., El-Monem, A. A. (2010): Alleviation of the potential impact of climate change on wheat productivity using arginine under irrigated Egyptian agriculture. Opions Méditerranéennes 95: 95-100.

[62] Hussain, S., Khan, F., Hussain, H. A., Nie, L. (2016a): Physiological and biochemical mechanisms of seed priming-induced chilling tolerance in rice cultivars. - Frontiers in Plant Science. doi: 10.3389/fpls.2016.00116.

[63] Hussain, S., Khan, F., Cao, W., Geng, M. (2016b): Seed priming alters the production and detoxification of reactive oxygen intermediates in rice seedlings grown under suboptimal temperature and nutrient supply. - Frontiers in Plant Science doi: 10.3389/fpls.2016.00439.

[64] Hussain, S., Yin, H., Peng, S., Khan, F. A., Khan, F., Huang, J., Cui, K., Nie, L. (2016c): Comparative transcriptional profiling of primed and non-primed rice seedlings under submergence stress. - Frontiers in Plant Science. doi: 10.3389/fpls.2016.01125.

[65] Hussain, H. A., Hussain, S., Khaliq, A., Ashraf, U., Anjum, S. A., Men, S., Wang, L. (2018): Chilling and Drought Stresses in Crop Plants: Implications, Cross Talk, and Potential Management Opportunities. - Frontiers in Plant Science. doi: $10.3389 /$ fpls.2018.00393. 
[66] Iqbal, S. (2009): Physiology of Wheat (Triticum aestivum L.) Accessions and the Role of Phytohormones under Water Stress. - Ph.D. Thesis, Fac. of Biological Sci., Quaid-i-azam Univ., Islamabad, pp. 83-154.

[67] Iqbal, M. A., Imtiaz, H., Muzammil, H. S., Essa, A., Zahoor, A. (2018): Probing profitability of irrigated and rainfed bread wheat (Triticum aestivum L.) crops under foliage applied sorghum and moringa extracts in Pakistan. - Custos e Agronegocio 14(2): 2-16.

[68] Jahan, M. A. H. S., Hossain, A., Jaime, A., Da Silva, T., EL Sabagh, A., Rashid, M. H., Barutçular, C. (2019): Effect of Naphthaleneacetic Acid on Root and Plant Growth and Yield of Ten Irrigated Wheat Genotypes. - Pakistan Journal of Botany 51(2): 451-459.

[69] Jat, L. K., Singh, S. K., Latre, A. M., Singh, R. S., Patel, C. B. (2013): Effect of dates of sowing and fertilizer on growth and yield of wheat (Triticum aestivum L.) in an Inceptisol of Varanasi. - Indian Journal Agronomy 58(4): 611-614.

[70] Joshi, A. K., Chand, R., Arun, B., Singh, R. P., Ortiz, R. (2007): Breeding crops for reduced-tillage management in the intensive, rice-wheat systems of South Asia. Euphytica 153(1-2): 135-151.

[71] Khajeh-Hosseini, M., Powell, A. A., Bingham, I. J. (2003): The interaction between salinity stress and seed vigour during germination of soybean seeds. - Seed Science Technology 31: 715-725.

[72] Khalili, M., Naghavi, M. R., Pour Aboughadareh, A. R., Talebzadeh, S. J. (2012): Evaluating of drought stress tolerance based on selection indices in spring canola cultivars (Brassica napus L.). - Journal of Agricultural Science 4(11): 78-85.

[73] Khan, A. A., Kabir, M. R. (2014): Evaluation of spring wheat genotypes (Triticum aestivum 1.) for heat stress tolerance using different stress tolerance indices. - Cercetari Agronomice in Moldova 47(4): 49-63. doi: 10.1515/cerce-2015-0004.

[74] Khichar, M. L., Niwas, R. (2007): Thermal effect on growth and yield of wheat under different sowing environments and planting systems. - Indian Journal Agricultural Research 41(2): 92-96.

[75] Kosina, P., Reynolds, M. P., Dixon, J., Joshi, A. (2007): Stakeholder perception of wheat production constraints, capacity building needs and research partnerships in the developing countries. - Euphytica 157: 475-483.

[76] Kuznetsov, V. V., Kholodova, V. P., Kuznetsov, V. V., Yagodin, B. A. (2003): Selenium regulates the water status of plants exposed to drought. - Doklady Biological Sciences 390: 266-268.

[77] Larkindale, J., Knight, M. R. (2002): Protection against heat stress induced oxidative damage in Arabidopsis involves calcium, abscisic acid, ethylene, and salicylic acid. Plant Physiology 128: 682-695.

[78] Larkindale, J., Huang, B. (2005): Effects of abscisic acid, salicylic acid, ethylene and hydrogen peroxide in thermos-tolerance and recovery for creeping bent-grass. - Plant Growth Regulator 47: 17-28.

[79] Li, R. H., Guo, P. G., Baum, M., Grando, S., Ceccarelli, S. (2006): Evaluation of chlorophyll content and fluorescence parameters as indicators of drought tolerance in barley. - Agriculture Science in China 5(10): 751-757.

[80] Mahboob, A. S., Arain, M. A., Khanzada, S., Naqvi, M. H., Dahot, M. U., Nizamani, N. A. (2005): Yield and quality parameters of wheat genotypes as affected by sowing dates and high temperature stress. - Pakistan Journal of Botany 37(3): 575-584.

[81] Majid, M. A., Islam, M. S., Sabagh, A. E. L., Hasan, M. K., Barutcular, C., Ratnasekera, D., Islam, M. S. (2017): Evaluation of growth and yield traits in corn under irrigation regimes in sub-tropical climate. - Journal of Experimental Biology and Agricultural Science 5(2):143-150.

[82] Manivannan, P., Jaleel, C. A., Sankar, B., Kishore, K. A., Somasundaram, R., Alagu, Lakshmanan, G. M., Panneerselvam, R. (2007): Growth, biochemical modifications and 
proline metabolism in Helianthus annuus L. as induced by drought stress. - Colloids Surf. B: Biointerf. 59: 141-149.

[83] Maralian, H., Ebadi, A., Didar, T. R., Haji-Eghrari, B. (2010): Influence of water deficit stress on wheat grain yield and proline accumulation rate. - African Journal of Agricultural Reserach 5(4): 286-289.

[84] Maria, A. M., Gendy, A. A., Selim, A. H., Abd El-All, A. M. (2008): Response of wheat plants grown under water stress in relation to Jasmonic acid. - Minufiya Journal of Agricultural Research 33(6): 1355-1375.

[85] Martiniello, P., Teixeira da Silva, J. A. (2011): Physiological and bio-agronomical aspects involved in growth and yield components of cultivated forage species in Mediterranean environments: A review. - European Journal of Plant Science and Biotechnology 5 (Special Issue 2): 64-98.

[86] Menshawy, A. M. M. (2007): Evaluation of some early bread wheat genotypes under different sowing dates:1 Earliness characters. - Fifth plant breeding conference (May). Egypt Journal of Plant Breeding 11(1): 25-40.

[87] Mirbahar, A. A., Markhand, G. S., Mahar, A. R., Abro, S. A., Kanhar, N. A. (2009): Effect of water stress on yield and yield components of wheat (Triticum aestivum L.) varieties. - Pakistan Journal of Botany 41(3): 1303-1310.

[88] Mitra, J. (2001): Genetics and genetic improvement of drought resistance in crop plants. Current Science 80: 758-762.

[89] Mondal, S., Singh, R. P., Mason, E. R., Huerta-Espino, J., Autrique, E., Joshi, A. K. (2016): Grain yield, adaptation and progress in breeding for early-maturing and heattolerant wheat lines in South Asia. - Field Crops Research 192: 78-85.

[90] Mostafa, H. A. M., Hassanein, R. A., Khalil, S. I., El-Khawas, S. A., El-Bassiouny, H. M. S., El-Monem, A. A. (2009): Effect of arginine or putrescine on growth, yield and yield components of late sowing wheat. - Journal of Applied Scientific Reserach 6: 177-183.

[91] Mumtaz, M. Z., Aslam, M., Nasrullah, H. M., Akhtar, M., Ali, B. (2015): Effect of Various Sowing Dates on Growth, Yield and Yield Components of Different Wheat Genotypes. - American-Eurasian Journal of Agricultural and Environmental Science 15(11): 2230-2234.

[92] Munns, R., James, R. A., Sirault, X. R. R., Furbank, R. T., Jones, H. G. (2010): New Phenotyping Methods for Screening Wheat and Barley for Beneficial Responses to Water Deficit. - Journal of Experimental Botany 61(13): 3499-3507.

[93] Nagodawithana, W. T. (1991): Yeast Technology. - Universal foods corporation Milwaukee, Wisconsin. Van Nostrand Reinhold, New York, 273 p.

[94] Nahar, K., Ahamed, K. U., Fujita, M. (2010): Phenological variation and its relation with yield in several wheat (Triticum aestivum L.) cultivars under normal and late sown mediated heat stress condition. - Notulae Scientia Biologicae 2(3): 51-56.

[95] Ogbaga, C. C., Stepien, P., Athar, H. U. R., Ashraf, M. (2018): Engineering Rubisco activase from thermophilic cyanobacteria into high-temperature sensitive plants. Critical Reviews in Biotechnology 38(4): 559-572.

[96] Out, H., Celiktas, V., Duzenli, S., Hossain, A., El Sabagh, A. (2018): Germination and early seedling growth of five durum wheat cultivars (Triticum durum desf.) is affected by different levels of salinity. - Fresenius Environmental Bulletin 27(11): 7746-7757.

[97] Patil, K. S., Durga, D. V., Phadnawis, B. N., Shivankar, R. S., Rathod, T. H. (2001): Effect of sowing dates on biomass production of wheat cultivars. - Annals of Plant Physiology 14(2): 115-119.

[98] Prasad, P. V. V., Pisipati, S. R., Ristic, Z., Bukovnik, U., Fritz, A. K. (2008): Impact of nighttime temperature on physiology and growth of spring wheat. - Crop Science 48: 2372-2380. 
[99] Rahman, M. M., Hossain, A., Hakim, M. A., Kabir, M. R., Shah, M. M. R. (2009): Performance of wheat genotypes under optimum and late sowing condition. International Journal of Sustainable Crop Production 4(6): 34-39.

[100] Ramirez-Vallejo, P., Kelly, J. D. (1998): Traits related to drought resistance in common bean. - Euphytica 99(2): 127-136.

[101] Rehman, A., Habib, I., Ahmad, N., Hussain, M., Khan, M. A., Farooq, J., Ali, M. A. (2009): Screening wheat germplasm for heat tolerance at terminal growth stage. - Plant Omics 2(1): 9-19.

[102] Reynolds, M. P., Delgado, M. I., Gutiérrez-Rodríguez, M., Larqué-Saavedra, A. (2000): Photosynthesis of wheat in a warm, irrigated environment. I: Genetic diversity and crop productivity. - Field Crops Research 66: 37-50.

[103] Reynolds, M. P., Trethowan, R. M. (2007): Physiological interventions in breeding for adaptation to abiotic stress. - In: Spiertz, J. H. J. (ed.) Scale and complexity in plant systems research, gene-plant-crop relations. Springer, Dordrecht, the Netherlands. pp. 129-146.

[104] Rosegrant, M. W., Agcaoili, M. (2010): Global food demand, supply, and price prospects to 2010. - International Food Policy Research Institute, Washington, D.C. USA.

[105] Rosielle, A. A., Hamblin, J. (1981): Theoretical aspect of selection for yield in stress and non-stress environment. - Crop Science 21: 943-946.

[106] Saleh, S. H. (2011): Performance, correlation and path coefficient analysis for grain yield and its related traits in diallel crosses of bread wheat under normal irrigation and drought conditions. - World Journal of Agricultural Science 7: 270-279.

[107] Shahin, Y., Valiollah, R. (2009): Effects of row spacing and seeding rates on some agronomical traits of spring canola (Brassica napus L.) cultivars. - Journal of Central European Agriculture 10(1): 115-122.

[108] Siddique, B. M. R., Hamid, A., Islam, M. S. (2000): Drought stress effect on water relation of wheat. - Botanical Bulletin of Academia Sinica 41: 35-39.

[109] Singh, S., Pal, M. (2003): Growth, yield and phenological response of wheat cultivars to delayed sowing. - Indian Journal of Plant Physiology 8(3): 277-286.

[110] Singh, S. (2009): Variation in physiological traits for thermos-tolerance in wheat. Indian Journal of Plant Physiology 14: 407-412.

[111] Slama, I., Rejeb, K. B., Rouached, A., Jdey, A., Rabhi, M., Talbi, O., Debez, A., Savouré, A., Abdelly, C. (2014): Presence of proline in salinized nutrient solution reenforces the role of this amino acid in osmoregulation and protects lipid membrane peroxidation in Arabidopsis thaliana. - Australian Journal of Crop Science 8: 1367-1372.

[112] Spiertz, J. H. J., Vos, J. (1985): Grain growth of wheat and its limitations by carbohydrate and nitrogen supply. - In: Day, W., Atkin, R. K. (eds.) Wheat growth and modeling. Plenum press, New York. p. 129-141.

[113] Stone, P. J., Nicolas, M. E. (1994): Wheat cultivars vary widely in their responses of grain yield and quality to short periods of post anthesis heat stress. - Australian Journal of Plant Physiology 21: 887-900.

[114] Subedi, K. D., Ma, B. L., Xue, A. G. (2007): Planting Date and Nitrogen Effects on Grain Yield and Protein Content of Spring Wheat. - Crop Science 47: 36-44.

[115] Subhani, R. (2010): Effect of temperature on development and grain formation in spring wheat. - Pakistan Journal of Botany 42(2): 899-906.

[116] Tarchoun, N., M'hamdi, M., Teixeira da Silva, J. A., Mehouachi, T. (2012): Approaches to evaluate the sensitivity of hot pepper floral structures to low night temperature. European Journal of Horticultural Science 77(2): 78-83.

[117] Thiaw, S., Hall, A. E. (2004): Comparison of selection for either leaf electrolyte-leakage or pod set in enhancing heat tolerance and grain yield of cowpea. - Field Crops Research 86: 239-253.

[118] Timsina, J., Connor, D. J. (2001): The productivity and sustainability of rice-wheat cropping systems: issues and challenges. - Field Crop Research 69: 93-132. 
[119] Ubaidullah, R., Mohammad, T., Hafeezullah, A. S., Nassimi, A. W. (2006): Screening of wheat (Triticum aestivum L.) genotypes for some important traits against natural terminal heat stress. - Pakistan Journal of Biological Science 9: 2069-2075.

[120] Upadhyay, R. G., Ranjan, R., Negi, P. S. (2015): Influence of sowing dates and varieties on productivity of wheat under mid Himalayan region of Uttarakhand. - International Journal of Tropical Agriculture 33(2): 1905-1909.

[121] Vollenweider, P., Gunthardt-Goerg, M. S. (2005): Diagnosis of abiotic and biotic stress factors using the visible symptoms in foliage. - Environmental Pollution 137: 455-465.

[122] Wahid, A., Gelani, S., Ashraf, M., Foolad, M. R. (2007): Heat tolerance in plants: An overview. - Environmental and Experimental Botany 61: 199-233.

[123] Wanas, A. L. (2002): Response of faba bean (Vicia faba, L.) plants to seed soaking application with natural yeast and carrot extracts. - Annals of Agricultural Science Moshtohor University 40(1): 83-102.

[124] Wang, G. P., Zhang, X. Y., Li, F., Luo, Y., Wang, W. (2010): Over accumulation of glycine betaine enhances tolerance to drought and heat stress in wheat leaves in the protection of photosynthesis. - Photosynthetica 48: 117-126.

[125] Wardlaw, I. F., Dawson, I. A., Munibi, P. (1989): The tolerance of wheat to high temperatures during reproductive growth: II. Grain development. - Australian Journal of Agricultural Research 40: 15-24.

[126] Wardlaw, I. F., Moncur, L. (1995): The response of wheat to high temperature following anthesis. I. The rate and duration of kernel filling. - Australian Journal of Plant Physiology 22: 391-397.

[127] Wardlaw, I. F. (2002): Interaction between drought and chronic high temperature during kernel filling in wheat in a controlled environment. - Annals of Botany 90: 469-476.

[128] Wazid, A., Hussain, A., Ahama, A., Ahamad, A. R., Ibrahim, A. M., Mussaddique, M. (2004): Effect of sowing date and plant population on biomass, grain yield and yield components of wheat. - International Journal of Agriculture and Biology 6: 1003-1005.

[129] Xia, Y. (2012): Photosynthesis-related physiological responses of field-grown maize to plant density and nitrogen stress during vegetative and reproductive stages. - Ph.D. Dissertation. Purdue University.

[130] Xu, Y., Xu, Q., Huag, B. (2015): Ascorbic acid mitigation of water stress-inhibition of root growth in association with oxidative defense in tall fescue (Festuca arundinacea Schreb.). - Frontiers in Plant Science 6(807): 1-14.

[131] Yassin, M., Mekawy, A. M., EL Sabagh, A., Islam, M. S., Hossain, A., Barutcular, C., Alharby, H., Bamagoos, A., Liu, L., Ueda, A., Saneoka, H. (2019): Physiological and biochemical responses of two bread wheat (Triticum aestivum L.) genotypes grown under salinity stress. - Applied Ecology and Environmental Research 17(2): 5029-5041.

[132] Yeganehpoor, F., Salmasi, S. Z., Kolvanagh, J. S., Golezani, K. G., Dastborhan, S. (2016): Changes in growth, chlorophyll content and grain yield of Coriander (Coriandrum sativum L.) in response to water stress, chemical and biological fertilizers and salicylic acid. - International Journal of Advanced Biological and Biomedical Research 5(1): 228-236.

[133] Yıldırım, M., Barutçular, C., Hossain, A., Koç, M., Dizlek, H., Akinci, C., Toptaş, I., Basdemir, F., Islam, M. S., EL Sabagh, A. (2018): Assessment of The Grain Quality of Wheat Genotypes Grown Under Multiple Environments Using GGE Biplot Analysis. Fresenius Environmental Bulletin 27(7): 4830 - 4837.

[134] Yordanov, I., Velikova, V., Tsonev, T. (2003): Plant responses to drought and stress tolerance. - Bulgarian Journal of Plant Physiology pp. 187-206.

[135] Zeidan, E. M., El-Hameed, A., Bassiouny, A. H., Waly, A. A. (2009): Effect of irrigation intervals, nitrogen and organic fertilization on yield, yield attributes and crude protein content of some wheat cultivars under newly reclaimed saline soil conditions. - Proc. of 


$$
-8332-
$$

the 4th Conf. on Recent Technol. in Agric. November 3-5, 2009, Cairo, Giza, Egypt. pp: 298-307.

[136] Zhang, J., Dell, B., Conocono, E., Waters, I., Setter, T., Appels, R. (2009): Water deficits in wheat: fructan exohydrolase (1-FEH) mRNA expression and relationship to soluble carbohydrate concentrations in two varieties. - New Phytologist 181: 843-850.

[137] Zhao, X. X., Liang, C., Fang, Y., Wang, Y. Q., Wang, W. (2007): Effect of glycinebetaine on function of thylakoid membranes in wheat flag leaves under drought stress. - Biologia Plantarum 51(3): 584-588.

[138] Zhu, L. H., van de Peppel, A., Li, X. Y., Welander, M. (2004): Changes of leaf water potential and endogenous cytokinins in young apple trees treated with or without paclobutrazol under drought conditions. - Scientia Horticulturae 99(2): 133-141. 